\title{
終戰後の葶業原料對策
}

山田久。夫

ポッダム宣言を受諾せる結果，北支，滿，鮮の攀土頁岩 礦, 南滿洲のマグネサイト磺を始めとして, 幾多の重要原料 地域を一時に舆失した我が國黨業界の前途は, 誠に容易なら ざるものがある。とより，原料の無い所几工栄は成立しな

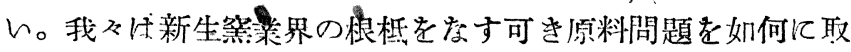
り扱つたらよんであららか。

一寸數へ上げても，ガラス原料としての曹達・加甲・矹 素, 高級中性耐火物原料としての攀土頁岩, 監基性耐火物原 料としてのマグネサイト，絕䋎磁器原料としての滑石等は，

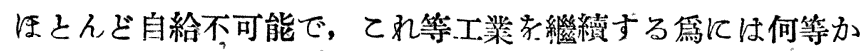
の方装を講じなければならない。

最も簡單飞考へられる解決策は，聯合軍司令部に輸入を中 請する事であるが，てれは現下の諸事情を考虑する時，“當分

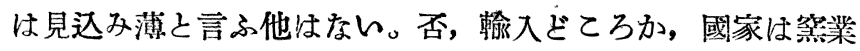
製品の一部（特に陶磁㤎，及び，セメント類）を賠償物資に充當 す可く期待して居るらしん。其の際, 我々は, “原料不足だ から出來ない”では濟されない。貴重な食料との交換物資と して, 政府が, 否、國氏全唓がたよりとするのを寒切る樣な 事为あつてはならない。かかる意味に於ても, 䈍業技術家, 並びに生產者の責任は誠に大であると言はねばならぬ“無” から”有”を生じ得なん事は, 大本洋戰爭で充分立證せられ たが，筆者は現在の羔業原料界の行きつまりを打開す可き方 策として，次の諸項を提案する。

1. 未利用資源の徹底的活用化を圖る事

從來, 原料として用みられないるのが, 研究を重ねた結 果, 立派几役立つ樣になつた例は, 点業界以外に少く存 い。(たとへば, 黃鐵餝は, 鐵の鑛石として使用されなかつた が, 最近, 米國に於て, 鐵鑪石として探用されるに至つた。） 本項の諭議對稱として取り上げらる可き未利用資源ば少くな いがなかにも重要なのは、マグネシア質原料としての蛇紋 岩である。湜鮮のマグネサイト碌, 滑石資源を器失しk今 日, 衁基性耐火物やステアタイト磁器等の原料自給を圖るに は, 本邦に豐富な蛇紋岩(北海道, 東北地方に多人, 特に岩手縣下 は有望)の活用を工夫する以外にないが, 外國に於ては, 既 に蛇紋岩の原料化の斯究が着々行はれて居るに拘らず, 我が 國に於て其の事のをくれて居るのは遺憾である。勿涂, 蛇旼 岩を原料とするには, 含有鐵分の多い事, 燒成收縮の大きい 事, 其の他の缺點があるが,・てれを如何に打開するかを科學 的に研究する事てそ, “新生科學技術者”としての突業汧究 芜の責務である。其他, 加里資源としての雲母片岩の㸴究, 珪砂原料として蛙目粘上砂部を使用する研究等, 今後, 科學 的に解決す可き未利用原料は少くない。

\section{2. 既開發資源の學術的整理，並びに系統化}

耐火粘土資源は，一本邦各地より數多く筂見報告せられ，其 の里藏量も相當大なりと推定されるが, 從來, 其の基礎研究

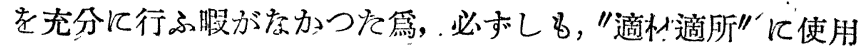
されて居らなかつた憾みがある。言ふ迄もなく，耐火物原料 としての粘土之，陶磁器原料としての粘土とでは其の要求さ れる性質が異る。したがつて, 各種黨業部門の夫ふに適當な 粘土を判定する必要があるが，それには，先づ夥多に上る各 地の粘土を, 片端しから, “學術的”に研究して分類・總轄せ ね代なら度ん，(同時に一應，埋藏量も調查する必要がある。） 相當年月のか」る厄介原仕事であるが，一度てれを完成して 置くと爾後の便利は蓝し想像外のものがあらう：

セメント原料としての各種石灰岩資源に就んても, 粘土類 と同樣な惠が言ひ得る。

\section{3. 新資源の調查, 開發}

狹い內地はもらしらべ盡したから，今更，調榃しても新資 源など發見出棑なかららとの意見もあららが，筆者は賛成出

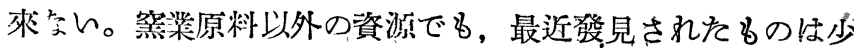
くない。たとへば, 最近北海道中央部附近で發見された水銀

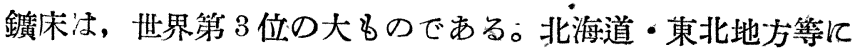
はまだ人跡非常に稀な區域があり，今後は，此の樣な所迄徹 底的汇涾查する必要がある。近時，長野縣下に新しく發胃さ れた蠟石鑛床 (パイロフィラィト以外にズニ石, ダイアスポアを含 む良質のむので, 埋藏量も少くない模栐）の如きは，まだまだ新 資源發見の可能性あるを.思はしめる。

\section{4- 海外よりの輸入促進}

以上三項の方策走强力に施行する傍ら，貿易に上り不足資

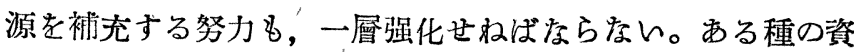
源仕，どらしても海外に仰がなければなら゙索い（曹達, 理砂 等)。文，若干は國內で自給し得ても，其の量の足りないもの (ダイアボポア碳，マグネシア筫原料，クロム質原料，加里，鉛等）に 就いても，極力原料輸入の才策を講じなりればならない。

本項の才策が理想的に遂行され」ば，前三項の必要性も大 いに減じるのであるが、本項は我々の希望だけでは實行に移 せるかどらかわからぬ。常識的に溚へて（船腹事情。その他 より判斷して), 此處數年間, 海外より輸大し得る原料は, 量 的に相當の制限を受けやゔ。しかし,"最善をつくしで努力 し續け，やがては日本が世界交易の華かな舞臺に乫入する基 礎をきづんて置く可きである。

以上の四方策は，平行して强力に行はねばならはいが、う ち始めの三項を效果的に實行するには，窯業以外の基礎學專 門家の援助を得る事が必要である。特に; 新資源の调查・開 發, 即開發資源の整理等を强力に行ふには, 地質學者の協力 を最も必要とする。乙れには"黨業家”にして、んくらか地 
質學のわかる人ぶではいけない。“地質学”の方が專門で

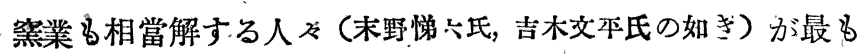

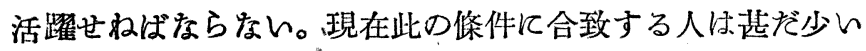
が，今後其の瘇充に努力す可をである。

筆者は地質學を專政せる者の一人として此處に一言所見索

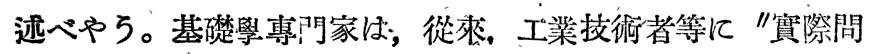
題をやらせると何も出來ない連中”之見られ勝ちである。箘 業原料問題の一牛を，若し地質學者溳つて貫はうとするな

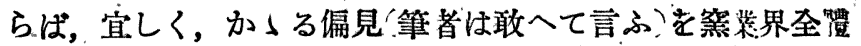
から，先づ一掃してかからね枋ならとと思ふ。，全或帝大か ら每年數十人の新地質學者が筫社會飞迩られて居るが，其の 中，每年 10 人くらねづつを，原料方面に活躍する人々とし て箘業界に迎へたんるのである。（自由主義時代となつたので， 恐しく明け放しの一交をるのしましたが, 差し障りがありましたら御 許しを气ふ)(昭和 20 年 12 月上 0 日夜)

\section{䇾業に關聯した學究的分野に於ける進むべき道}

\section{山口悟 郎}

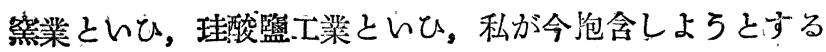
巧業分野を表現する汇適當存言葉が見當らないが，應用鈸物

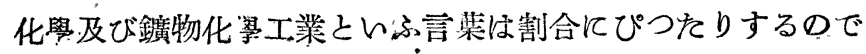

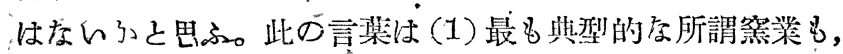

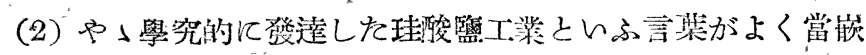

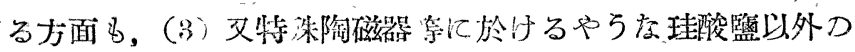

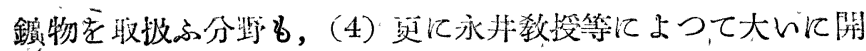
拓されたアルミナ抽出とか, 矹酸抽出のやうな“Cbemic 1

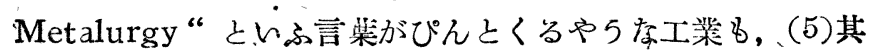

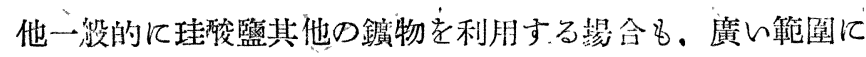
亘り何れも上く包含して为るやら江思ふ。しかし黨業といふ

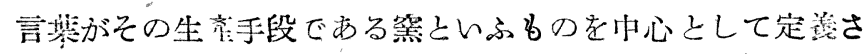
れたのであるとすれば，今氺が，取披ふ原料の自然科學的性

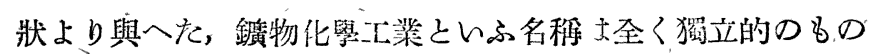

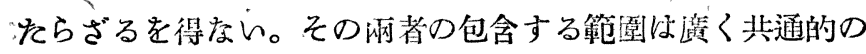
るのであるが,”業といふ立場からすれば, 的省の定義により

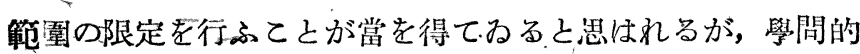
對照として取上げる圽合には，後者の定我に上る方が便利で

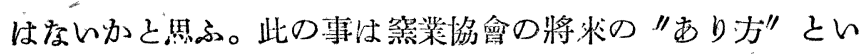

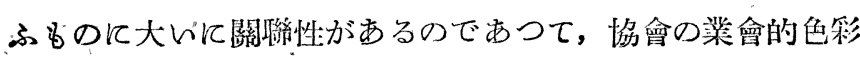
之，學會的色彩の何几を浱厚にす心きか，或は兩者分立の形 體にすべきかによつて，夫ふに適した方倽及び組織圭明確に して置くべきものと出ふ。しかし今は斯る題目につんて諭議 するのが目的でないから，之以上深入しないてととする。

哏を廣く轉じて, 物理學及び化學沉於ける純料學理の進步

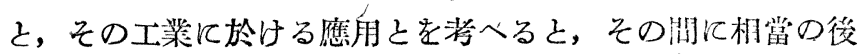

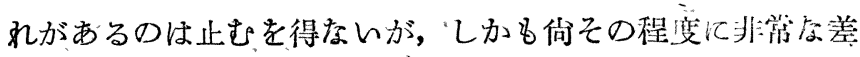

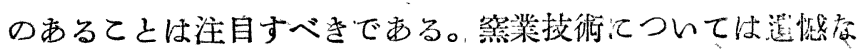
がら學理の進步に最も遠く取殘されたものの一うであるてと を認めざるを得ない。之は本問題㷪つた人々の不勉强のみ の問題でなく，本質的難しさに基く部分が相當あり，從つて 之が學問的體系を形作るまでには，未だ多くの稌地が殘さ れ，又努力を必要とするるのである。殊化我國に於ては總て

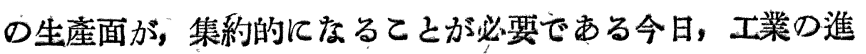

むべき道も，質を茂にした大量生產でなくして；質的向上に

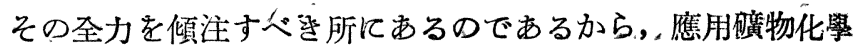
の體系つ確立は本工業の發展に不可缺であると信和る。

本工業は鑛物質の利用にあるのであつて, その原炓江大體 に於て結晶質で, 取扱は多く固體反應乃至夫れに近い狀態で 西り，從つて學問湖基礎を置くべき所は自ら明である。但し

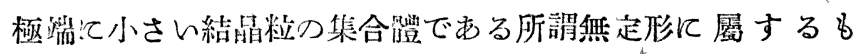

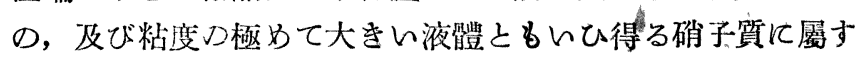

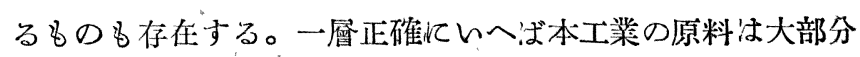
結晶筫鈸物で歹り，時飞硝子質鐎物を利用するといて得る。 しかしでその䑪物は珪酸監であるてとが非常に多いのであ る。斯る原料沦對して, 現在一工業上賽施されてみるる取扱

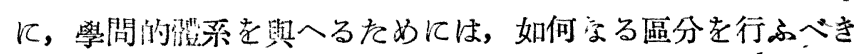
かといふに，私は次のやうな區分を探りをいと思ふ。
1. 原料寎する事項
2. 化學工學的問題江關する重項
3. 加工に關する事項
4. 合成渻する事項
5. 分解及び抽出に關する事頁
6. 硝子化几關する事項

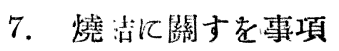

第一の原料汇關する事項，之㵊飞根柏的重要問題であつ て，我ぬとしては少くとも國內の資源偖對しては，其の性狀

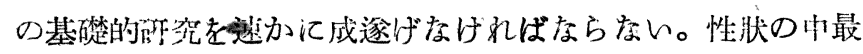
重要孛るものは主成分鈸物の鑛物學的性狀であつて, 之に

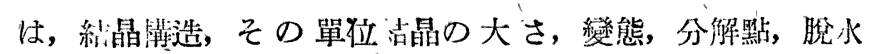

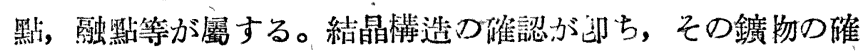
認になるのであるから，之帟對的のもので，今つ所 $\mathrm{x}$ 線的 解析にに上るのが唯一の廣く適用し得 $\tau$, 信: 員し得る方法

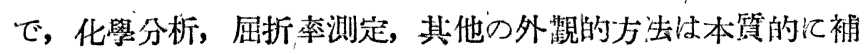

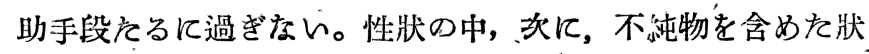
態に於ける檢討が必要である。即ち不純物の量及び質, 不均 一的存在か或は固溶體的存在か, 除去の能否, 種々の使用目 的て對する性能奎が之に屬する。使用目的に對する性能の检 